\title{
FROM TECHNOCRATIC PRAGMATISM TO THE DEVELOPMENTAL MARKET: CONCEPTUALISING THE POLITICS OF BREXIT IN TERMS OF THE RIVALRY OF TWO DIFFERENT POLITICAL ECONOMIES
}

\section{Simon LEE*}

\section{Abstract}

At the 5 June 1975 European Community referendum, England voted 68.7\% in favour of the United Kingdom staying in the European Community (common market), making it the most Europhilic of the nations of the United Kingdom. On the 23 June 2016, England was the most Eurosceptic of the United Kingdom's nations, voting 53.3 per cent to leave the European Union, and with every administrative region outside of London voting to leave. To account for this great transformation in English public opinion, this article explores the politics of Brexit by focusing upon the rivalry of two contrasting domestic political economies and their different attitudes towards supranational integration. On the one hand, the political economy of 'technocratic pragmatism' has seen membership of and access to the Common Market as a means by which a continental European technocratic "developmental state" blueprint for British industrial modernization could be secured. On the other hand, the political economy of the 'developmental market' has seen the 'continentalization' of the European Union 'super-state' as a threat to the restoration of an entrepreneur-led liberal market order based upon England's foundational traditions of common law, individual liberty and representative democracy. The politics of Brexit, and the outcome of the 23 June 2016 referendum, can therefore be understood as a victory for the proponents of the developmental market over advocates of technocratic pragmatism, and a manifestation of how politics in England, long before Brexit, had become stranded on the common ground of the neo-liberal developmental market.

Keywords: Brexit, technocratic pragmatism, development market, neoliberal developmental market.

\footnotetext{
${ }^{*}$ Senior Lecturer, Department of Politics, University of Hull, s.d.lee@hull.ac.uk
} 


\title{
TEKNOKRATIKK PRAGMATIZMDEN GELISŞIM PAZARINA: İKI FARKLI SIYYASI EKONOMININ REKABETI BAKIMINDAN BREXIT SIYASETINII KAVRAMSALLAŞTIRMA
}

\author{
$\ddot{O} z$
}

5 Haziran 1975'de Avrupa Topluluğu Referandumunda Birleşik Krallık'ın Avrupa Topluluğu'nda (ortak pazar) kalması yönünde kullandığ \% 68.7'lik oy ile Ingiltere, kendisini Birleşik Krallık'ın en Avrupa taraftarı ulusu yapmıştır. 23 Haziran 2016 Referendumunda ise, Londra dişındaki her bir idari birimde, \%53.3 oranında ayrlma yönünde oy kullanan İngiltere, Birleşik Krallık uluslart içinde en Avrupa şüphecisi ulus olmuştur. Ingiliz kamuoyunda yaşanan bu büyük değişimi açıklamak için, bu makale iç politika alanında muhalif iki siyasi ekonominin ulusüstücü bütünleşme konusundaki farklı tutumlarına ve aralarındaki rekabete odaklanarak Brexit siyasetini incelemektedir. Bir tarafta Ortak Pazar üyeliğini ve erişimini kıta Avrupasi teknokratik 'gelişim devleti' modeli vasitasiyla Britanya sanayisinin modernizasyonunu güvence altına alabilecek bir araç olarak gören siyasi ekonominin 'teknokratik pragmatizmi' vardır. Diğer tarafta ise, Avrupa Birliği'nin 'süper devletinin' 'kltasallaşmasını', Ingiltere'nin temelini oluşturan hukuk, bireysel özgürlük ve temsilî demokrasi geleneklerine dayanan müteşebbis liberal pazar düzeninin restorasyonuna bir tehdit olarak gören "gelişim pazarı'nın” siyasi ekonomisi bulunmaktadır. Bu nedenle Brexit siyasetinin ve 23 Haziran 2016 referandumunun sonuçlarl, gelişim pazarl savunucularının teknokratik pragmatizm savunucularına karşı bir zaferi ve Brexit'ten çok önce Ingiltere'de siyasetin neo-liberal gelişim pazarı ortak temelinde nasıl tıkanmış olduğunun bir göstergesi olarak anlaşılabilir.

Anahtar Kelimeler: Brexit, teknokratik pragmatizm, gelişim devleti, neoliberal gelişim pazarl.

\section{Introduction: European Integration as a Means to an End}

At the 5 June 1975 European Community referendum, England voted 68.7\% in favour of the United Kingdom staying in the European Community (common market), making it the most Europhilic of the nations of the United Kingdom. On the 23 June 2016, England was the most Eurosceptic of the United Kingdom's nations, voting 53.3 per cent to leave the European Union, and with every administrative region outside of London voting to leave. To account for this great transformation in English public opinion, this article explores the politics of Brexit (British exit from a European supranational institution) by locating it within the broader and much more longstanding debate about the 
relative decline of the United Kingdom, and the place of European supranational integration in programmes for remedying national decline.

The article focuses upon two contrasting political narratives about national decline, themselves the products of two rival political economies and two very different interpretations of English and British history. The first, the political economy of 'technocratic pragmatism', has seen membership of and access to the Common Market as a means by which a continental European technocratic blueprint for industrial modernisation could be secured. The second, the political narrative of the 'developmental market', has seen the 'continentalization' of the European Union 'super-state' as a threat to the restoration of entrepreneur-led liberal market order, based upon England's foundational traditions of common law, individual liberty and representative democracy. The politics of Brexit, and the outcome of the 23 June 2016 referendum, can therefore be understood as a victory for the proponents of the developmental market over advocates of technocratic pragmatism, and a manifestation of how politics in England, long before Brexit, had become stranded on the common ground of the neo-liberal developmental market.

The United Kingdom is currently navigating towards its second Brexit. Previously, on the 16 September 1992, the United Kingdom had exited from the Exchange Rate Mechanism of the European Monetary System. To comprehend the politics of Brexit, it is first necessary to understand the politics of the United Kingdom's membership of the European Community/European Union. To do so requires in turn an understanding of the role and location which the project of supranational European integration has occupied in relation to the central peacetime political debate and narrative which has dominated British politics from the last quarter of the nineteenth century to the present day: the relative decline of the United Kingdom, and how to reverse it.

During the period since the end of the second world war, United Kingdom politics has been shaped by a series of state-led modernization programmes. United Kingdom membership of the European Community (since 1 January 1973), and (since 1 November 1993) the European Union, has been seen by British governments in pragmatic, instrumental terms, and in relation to their respective programmes for reversing British decline. During the five separate occasions the United Kingdom has held the presidency of the Council of the European Community/European Union, no serving Prime Minister has made a speech endorsing the project of an ever-closer supranational political union, with the United Kingdom at the heart of it, as a vital British national interest or a remedy for relative economic decline. On the contrary, they instead expressed their commitment to the United Kingdom remaining at the heart of a Europe of sovereign nation states cooperating on an intergovernmental basis, rather than as part of an ongoing supranational integration designed from the Treaty of 
Rome onwards to bring about "an ever-closer union among the peoples of Europe" (European Community, 1957).

For British Prime Ministers and their governments, membership of the European Community/Union has served two express purposes. First, to enable the United Kingdom to have access to a large single market and customs union, which it was hoped might serve to enhance national competitiveness and contribute to the reversal of relative economic decline. Second, to help the United Kingdom, during the era of its loss of its empire, to continue to be, if not a de facto 'Great Power', then an active player on the world stage in matters relating to global governance and the provision of international and global public goods. The British power elite has continued to regard the United Kingdom as a global actor with global security, geo-political, financial and commercial interests, Europe has always been of secondary importance in the calculation of British foreign policy.

\section{Europe as 'The Other': Technocratic Pragmatism and the Quest for a British Developmental State}

In the politics of Brexit, Europe and European integration have been cast in the role of "the Other", i.e. a model of political economy either to be admired and copied as a superior blueprint for national development, or a model to be shunned as an inferior political economy. The perspective towards Europe of British modernization programmes has been shaped by whether those programmes have been advocates of technocratic pragmatism, i.e. a state-led industrial modernization programme to be fashioned by a British developmental state, or proponents of the neo-liberal developmental market, i.e. the remedying of national decline by a rolling back of the frontiers of the state to restore the entrepreneur and the open market as the twin drivers of economic and social change. For technocratic pragmatists, European integration, via its forging of a common and latterly single European market, has been a means towards the end of a developmental state, a state which accords greatest precedence to industrial policy, i.e. "a concern with the structure of domestic industry and with promoting the structure that enhances the nation's international competitiveness" (Johnson, 1982: 19). For technocratic pragmatists, it has been the absence of such an industrial policy which has been the principal cause of the relative decline of British industrial decline (Heseltine, 1987; 2017).

Technocratic pragmatism and the quest for a British developmental state-led industrial modernization programme has been a project which has featured in the politics of both the Labour Party and Conservative Party. However, in relation to the potential for membership of the European Community to further this end, it was the Conservative Government of Harold Macmillan (19591963) which first saw domestic political and economic advantage in British 
membership of the European Community, formally applying for membership on the 10 October 1961 with Edward Heath serving as lead negotiator for the Macmillan Government. Subsequently, the Conservative Government of 19701974, led by Heath himself as Prime Minister, would successfully negotiate the United Kingdom's entry to the European Community from the 1 January 1973. What was significant about Macmillan and Heath was that they were the two most eminent exponents of a longstanding tradition of technocratic pragmatism within the Conservative Party.

It is not hard to understand why technocracy and conservatism should have proven such easy and longstanding ideological bedfellows. On the one hand, technocracy has been defined as "a system of governance in which technically trained experts rule by virtue of their specialist knowledge and position in dominant political and economic institutions" (Fischer, 1990: 17-18). Technocracy has regarded politics and ideology as problems rather than solutions, but ones which could be surmounted by if the political will could be found to redefine political issues in scientific and technical terms (Fischer, 1990: 22). Technocracy had pointed towards a "uniquely administrative or managerial" conception of the state, with the state itself being held to be "a positive instrument in the pursuit of economic and social progress" on account of its being "the only institution capable of engaging in comprehensive systemwide planning and management" (Fischer, 1990: 25). On the other hand, conservatism has shared with technocracy both its belief in government by an expert governing class, and its distrust of political ideology.

When the United Kingdom economy encountered the mass unemployment of the 1920s and the Great Depression of the 1930s, some within the Conservative Party turned to technocratic blueprints for industrial modernization. Foremost among these Conservative technocratic pragmatists was Harold Macmillan. Having advocated a policy of reconstruction to the National Government in 1931, three years later Macmillan published Reconstruction: A Plea for A National Policy. In it, Macmillan argued "We must realise the essential contradictions of laissez-faire while we may appreciate the energy and drive of a rugged individualism" (Macmillan, 1934: $6)$. In developing the case for the planning of production, Macmillan argued the choice was "no longer as between industrial laissez-faire and monopoly; but between trustification and socialisation, or, it may be, between orderly capitalism and economic and social disorder" (Macmillan, 1934: 22).

Having set out a detailed technocratic blueprint for the co-ordination of financial, industrial and political policy, in 1938 Macmillan published The Middle Way, an even more detailed technocratic blueprint for advancing "more rapidly and still further, upon the road of conscious regulation" (Macmillan, 1938: 11). Macmillan insisted that the purpose of his technocratic blueprint for 
industrial reorganisation was "avowedly that of restoring to the individual the greatest possible measure of freedom", but acknowledged simultaneously that "Economic efficiency and rational social organisation may be sought by nations for other ends" (Macmillan, 1938: 371).

The true political significance of Macmillan's technocratic pragmatism was not fully evident until 1947, when it formed the basis for The Industrial Charter: a statement of Conservative industrial policy (Conservative Party, 1947). Its publication signalled the modernization of Conservative policy and the casting aside of laissez-faire economics in favour of a system of "humanized capitalism" through which "modern Conservatism would maintain strong central guidance over the operation of the economy" (Butler, 1971: 145). Thereafter, under successive Conservative Governments from 1951-1964, and under the Heath Government of 1970-1974, the Conservative Party remained a proactive party of industrial modernization and the prime mover of closer links to Europe, symbolized by its commitment to major projects of European industrial collaboration, of which the Anglo-French Concorde project was the most salient.

Edward Heath was in essence the quintessential modernising technocratic pragmatist, "a technological managerial man looking to a European commitment to aid the regeneration of competition in industry" (Holmes, 1982: 11). As his biographer John Campbell has suggested, Heath believed that "British industry needed to become more efficient and the economy more competitive". Indeed, like the true Tory technocrat he was, Heath "had no interest in political philosophy or economic theory", and simply thought "making Britain prosperous and successful was a matter or practical common sense and political will, vigorously applied" (Campbell, 1993: 193-4). On becoming Prime Minister in June 1970, Heath's "Quiet Revolution" was about the application of modern business efficiency and managerial techniques to the reorganization of central and local government. In due course, the Heath Government would rescue both Rolls-Royce and Upper Clyde Shipbuilders, and pass the 1972 Industry Act, which incorporated extensive powers for discretionary assistance to private industry (Lee, 1996). Ironically, in also passing the 1971 Competition and Credit Control Act, which began the process of major financial liberalization in the United Kingdom by replacing administrative guidance with market supply of credit by the banking system, the Heath Government also initiated the first significant act in the creation of the neo-liberal developmental market that was to be championed later in the decade by Margaret Thatcher and her ideological ally Sir Keith Joseph.

One of the principal beneficiaries of the Heath Government's technocratic pragmatism in the early 1970s was the political career of Michael Heseltine. As Minister for Aerospace, in 1973 Heseltine was a prime mover of the 
establishment of the European Space Agency, and the rationalization and coordination of individual national space programmes. A decade later, as Defence Secretary in the second Thatcher Government, Heseltine played a key role in the creation of the European Fighter programme, a four nation consortium of Germany, Italy, Spain and the United Kingdom, which replicated and expanded the pattern of collaborative European defence procurement and industrial policy which had been forged from the late 1960s by the earlier Tornado Multi Role Combat Aircraft, and in which the United Kingdom had been a partner since 1968 (Heseltine, 1989: 203).

Befitting a technocratic pragmatism, committed to state-led industrial modernization via a closer working relationship with Europe, when Heseltine resigned dramatically from the Thatcher Government on the 9 January 1986, his resignation arose from divisions within the Cabinet over whether the United Kingdom's sole helicopter manufacturer, Westland plc, should be taken over by a European consortium, in which British Aerospace would take a leading role, or by a rival consortium led by the American manufacturer Sikorsky. Because it would fit in with the developing pattern of European collaboration, to comply with the 1978 Declaration of Principles agreed by the United Kingdom, France, Germany and Italy to "make every effort to meet their needs with helicopters developed jointly in Europe" (Heseltine, 2000: 535), Heseltine had favoured the European bid. His resignation had been prompted by what he saw as the failure of the Thatcher Government to maintain its official stated position of an evenhanded approach between the viable offers, and the attempts of the Prime Minister to constrain his capacity to answer questions, as the Cabinet minister responsible for defence procurement, by an insistence that all such matters should be referred to the Cabinet Office for collective clearance (Heseltine, 2000).

Following his resignation, Heseltine duly published two books which reaffirmed the technocratic pragmatism vision of the necessity of pursuing an industrial strategy both at the United Kingdom and European levels. First, in Where There's A Will, Heseltine set out what was, in effect, an alternative programme of government to Margaret Thatcher's developmental market agenda, by advocating a major administrative reorganization of central government responsibilities which would have seen the then Department of Trade and Industry refashioned into the British equivalent of the Japanese Ministry of International Trade, to serve as the pilot agency of a British developmental state, with new powers to challenge the power of the Treasury and its fixation with shorter term fiscal matters rather than longer term strategic industrial priorities (Heseltine, 1987: 82-129). Second, in The Challenge of Europe: Can Britain Win?, Heseltine argued "The tide of history has carried us close to Europe's shores. We should accept that destiny; the wind will never be 
more favourable" (Heseltine, 1989: xiv). In setting out "the practical arguments for Europe", via a classic technocratic blueprint for modernization through supranational integration, Heseltine contested that with "no empire to sustain us; we are no longer an industrial super-power; we can no longer pretend that Britain is in any sense an equal partner of the United States. There is nowhere for us to go except as part of a European consortium" (Heseltine, 1989: 14).

\section{Europe as "The Other": The Restoration of The Developmental Market}

The rationale of Edward Heath's technocratic "Quiet Revolution", with its major efficiency-driven administrative reorganizations at home, and its successful negotiation of United Kingdom membership of the European Community externally, had been improved economic performance, rising real living standards, and the reversal of British decline. In the event, the Heath Government's "Revolution" was anything but quiet. Instead, it delivered rising inflation and economic stagnation ("stagflation"), industrial unrest, a state of emergency, and consecutive General Election defeats for the Conservative Party in February and October 1974.

This economic and political failure for both their political party and their nation prompted two members of the Heath Government, Education Secretary Margaret Thatcher and Social Security Secretary Sir Keith Joseph to launch a political project which would commence by questioning the whole post-1918 political settlement in the United Kingdom, and culminate in the vote for "Brexit" in the 23 June 2016 European Union referendum.

Following the Conservative Party's February 1974 General Election defeat, Sir Keith Joseph spurned the opportunity to serve in Heath's Shadow Cabinet, but instead sought Heath's consent to establish a new think tank, the Centre for Policy Studies, ostensibly to undertake studies of the United Kingdom's principal competitors to better understand the reasons for their superior economic performance. Heath's biographers have recorded that he reportedly thought the exercise would be good for both Joseph and Thatcher, as they would learn more about the problems of industry (Campbell, 1993: 627; Ziegler, 2010; 450). In the event, the Centre for Policy Studies was established independent of and parallel to the Conservative Party's policy-making structure with a very different purpose in mind. Its European comparisons would "survey the scope for replacing increasingly interventionist government by social market policies, and seek to change the climate of opinion in order to gain acceptance for them" (Joseph, 1975: 3).

Rather than a technocratic exercise in the more efficient administration of the politics and government of the existing Keynesian social democratic welfare state political settlement, what was being orchestrated was nothing less than a reversing of that trend, through an ideological counter-revolution which would 
recast the United Kingdom's understanding of its interests in its relationship with Europe. The focus would be "Political Economy, not Economics" (Thatcher, 1975) and the reintroduction of a wholesale debate about the respective roles of the state and market, rather than a much narrower technocratic discourse on questions of efficiency in public policy administration.

From this juncture, in Conservative Party elite thinking would no longer conceive of the United Kingdom's relationship with Europe and supranational integration as a means to forward the objective of achieving a British developmental state-led industrial modernization programme. On the contrary, the objective would be to roll forward the frontiers of a decentralized developmental market or "competitive capitalism" model of political economy, as "part of a wider belief in the freedom of personal choice which implies the limitation of state power and the encouragement of individual initiative" (Joseph, 1975: 12). The European social market economy which had inspired Joseph and Thatcher was not the social democratic variant enshrined in the 1959 Bad Godesberg programme of the Social Democratic Party of Germany, but the ordoliberal variant created by Alfred Muller-Armack of the Freiburg school of political economy, which was enshrined in the 1949 Dusseldorf programme of the German Christian Democratic Party, and popularized by Ludwig Erhard, the Minister of Economic Affairs in the Adenauer governments (Brack, 1989: 17). This particular social market economy would mean advocacy of low taxation, minimal state intervention and therefore implacable opposition to the idea of both a welfare and a developmental role for the state (Brack, 1989: 12).

In establishing the Centre for Policy Studies, Thatcher argued "Unless we make a dispassionate assessment of past economic performance as a prelude to action, we are likely to continue along a path of drift and decline" (Thatcher, 1977: 87). Success would depend upon "winning not just power but the battle of ideas" (Thatcher, 1977: 51). British politics had become stranded on a collectivist "middle ground", characterized by Britain being "over-governed, over-spent, over-taxed, over-borrowed and over-manned" (Joseph, 1976a: 19). As a remedy, Thatcher and Joseph's developmental market agenda was based upon an unshakeable faith in enterprise and entrepreneurs, "the adventurers who strike out in new directions in science, technology, medicine, commerce and industry" (Thatcher, 1977: 35). Innovation and advance would be possible in every field of British society, if entrepreneurs were once again given the opportunity to take risks to discover profitable innovations in the freedom provided by open markets. This analysis was based upon the insight from neoAustrian economics that markets are spontaneous discovery processes, not centrally planned systems, the product of "human action but not of human 
design" (Hayek, 1967: 105 cited in Shand, 1984: 64). The political economy of the developmental market assumed the superiority of entrepreneurial knowledge over the scientific knowledge claimed by the modernizers of the Conservative tradition of technocratic pragmatism from Macmillan to Heseltine. The key to remedying national decline would be the rediscovery of the missing dimension of economic policy, namely the entrepreneur, and the restoration of "personal prosperity creation because, in a free society, it is the only route to national prosperity-creation" (Joseph, 1976b: 14-15).

Central to this political and ideological counter-revolution was the influence of the political economy of Friedrich Hayek upon the thinking of both Thatcher and Joseph. It was in April 1974 that (the then) Sir Keith Joseph experienced the political and ideological revelation that he had only just been converted to conservatism. As he later confessed, "I had thought that I was a Conservative but I now see that I was not really one at all” (Joseph, 1975: 4). In truth, Joseph's conversion was not to conservatism, but from conservatism to what is now known as neo-liberalism, the ideological foundation of the developmental market. This fact was famously later confirmed when, in May 1979 and on becoming Secretary of State for Industry in the first Thatcher government, the reading list of 29 works Joseph had circulated to his senior civil servants had included major works of classical liberal political economy, notably by Adam Smith, but not a single text on conservatism (Bosanquet, 1981). For her part, when Margaret Thatcher was asked by the pressure group, Aims of Industry, to nominate her three favourite books on liberty, one of her three choices had been Friedrich Hayek's The Constitution of Liberty (Hayek, 1960).

In Hayek's postscript to this work, entitled "Why I am not a conservative", Hayek had stated that because of its "widespread attitude of opposition to drastic change", by its very nature conservatism could not "offer an alternative to the direction in which we are moving" (Hayek, 1960: 344). Hayek duly depicted the relationship between liberalism, conservatism and socialism diagrammatically, in the form of a triangle. Each ideology had occupied one corner of the triangle, but because the socialists had "for a long time been able to pull harder, the conservatives have tended to follow the socialist rather than the liberal direction" (Hayek, 1960: 344). Indeed, the conservatives had "compromised with socialism and stolen its thunder" (Hayek, 1960: 344). In this regard, Hayek highlighted the work of Harold Macmillan, because as "Advocates of the Middle Way with no goal of their own, conservatives have been guided by the belief that the truth must lie somewhere between the extremes-with the result that they have shifted their position every time a more extreme movement appeared on either wing" (Hayek, 1960: 344). There could have been few more damning critiques of the ideological foundation of the Conservative variant of technocratic pragmatism. 
Hayek's analysis was itself based upon a particular and highly selective reading of England's history, and especially its relationship with Europe. Hayek asserted that the ideas of classical liberalism he had been seeking to restate in The Constitution of Liberty had originated with "the ideals of the English Whigs that inspired what later came to be known as the liberal movement in the whole of Europe" (Hayek, 1960: 352). Therefore, for Hayek, "Whiggism is historically the correct name for the ideas in which I believe. The more I learn about the evolution of ideas, the more I have become aware that I am simply an unrepentant Old Whig-with the stress on the "old"' (Hayek, 1960: 353).

In his much earlier work, The Road to Serfdom in 1944, Hayek had warned of the dangers that the socialist and collectivist "Road to Freedom was in fact the Road to Servitude" (Hayek, 1944). Here, Hayek's thesis was that, after 1870, "England lost her intellectual leadership in the political and social sphere and became an importer of ideas" (Hayek, 1944: 16), namely collectivist ideas and institutions imported from Germany, "Whether it was Hegel or Marx. List or Schmoller, Sombart or Mannheim, Hegel or Marx" (Hayek, 1944: 16). In the process, private ownership and private enterprise had been displaced as the prime movers of progress by "the creation of a system of 'planned economy' in which the entrepreneur working for profit is replaced by a central planning body" (Hayek, 1944: 24). Having "lost their own belief in the peculiar values of English civilisation", for Hayek "The Left intelligentsia, indeed, have so long worshipped foreign gods that they seem to have become almost incapable of seeing any good in the characteristic English institutions and traditions" (Hayek, 1944: 160).

Hayek had revisited this historical narrative about England's changing relationship to Europe in The Constitution of Liberty (Hayek, 1960), his restatement of the doctrines of nineteenth century classical liberalism. Here, Hayek had noted how "Individual liberty in modern times can hardly be traced back farther than the England of the seventeenth century...And for over two hundred years the preservation and perfection of individual liberty became the guiding ideal in that country" (Hayek, 1960: 142). Thus, for Hayek, seventeenth century England had witnessed the conception of limited government, a new departure in English statecraft, while the liberty of the individual was "a byproduct" of the English Civil Wars (Hayek, 1960: 146). Indeed, he concluded: "the ideals of the English Whigs that inspired what later came to be known as the liberal movement of the whole of Europe" (Hayek, 1960: 352).

Inspired by Hayek, Thatcher and Joseph's developmental market agenda was therefore not a project of modernization, but rather a project of restoration. The foundation of the Centre for Policy Studies was to be the first stepping stone on an ideological and political odyssey which would witness the rediscovery and restoration of entrepreneurship, the "missing dimension in 
economic policy", as a reaction to and critique of the previous crowding out of the market from the political imagination, in both ideological and policy terms, arising from the fixation with the developmental state and technocratic modernization.

\section{Building a Written Constitution for The Market: Stepping Stones to Brexit}

The scale of both the ambition and the task confronting the project to restore a developmental market was first set out in Stepping Stones, a strategy drawn up by businessmen Sir John Hoskyns and Norman Strauss for Margaret Thatcher in November 1977. It stated: "The task of the next Tory Governmentnational recovery-will be of a different order from that facing any other postwar government. Recovery requires a sea-change in Britain's political economy" (Hoskyns and Strauss, 1977: 2). Indeed, after Thatcher had led the Conservative Party to victory in the May 1979 General Election, Sir Keith Joseph had used his first speech as Secretary of State for Industry to affirm that his government had brought with it "a different analysis and a different set of policies" to address the "six main obstacles to full employment and prosperity", which Joseph identified as high state spending, high direct taxation, egalitarianism, nationalization, a Luddite trade union movement and an antienterprise culture (Joseph, 1979: 706-11).

This very different agenda for redressing the United Kingdom's relative economic decline did not of itself immediately trigger conflict with the process of European supranational integration and the ambition to build an ever-closer union of the peoples of Europe. The majority of the first two terms of the Thatcher Governments were devoted instead to surmounting domestic rather than supranational obstacles to the rolling forward of the frontiers of the developmental market via policies of privatization, and market liberalization and deregulation. However, at the Fontainebleau Summit in June 1984, not only had agreement been reached on the European Community's future budget, which would include a rebate on the United Kingdom's contribution that would reduce it to 66 per cent of the planned total, but the commitment to forwarding a "A People's Europe" had included the pledge to draw up a single document on the movement of goods by mid-1985 (European Commission, 1984: 2). This provided Thatcher with the opportunity "to provide impetus to the Community's development as a free trade and free enterprise area", by driving forward her "one overriding positive goal" in relation to supranational integration which was the creation of "a single Common Market" (Thatcher, 1993: 546, 553).

At the Dublin Summit of the European Council in December 1984, it was agreed that the Council should take steps to complete the Internal Market. 
Thatcher's nominee as the new United Kingdom European Commissioner, Lord Arthur Cockfield whom she described as "a natural technocrat" (Thatcher, 1993: 547), had from January 1985 assumed the role of Commissioner for the Internal Market and Services, and so he was in a prime position to implement Thatcher's ambition to roll forward the frontiers of developmental market deregulation and liberalization at the supranational level. At the June 1985 Milan Summit of the European Council, the European Commission was duly able to present its White Paper, Completing The Internal Market (European Commission, 1985). This in turn led to agreement that a fully unified Single Market should be completed by 1992, and this agreement was enshrined with the signing of the 1986 Single European Act in February 1986. Thatcher had intended that the Single Market, as part of the first major revision of the 1957 Treaty of Rome, would reaffirm the Treaty as "a charter for economic liberty" by reviving "its liberal, free trade, deregulatory purpose" (Thatcher, 1993: 5467). Instead, because the Single European Act would include measures to extend the powers of the European Parliament and introduce qualified majority voting into the Council of Ministers, Thatcher would find her vision and developmental market model of political economy increasingly at odds with a very different, but equally clear vision and alternative model articulated forcefully by Jacques Delors, the President of the European Commission: that of economic and monetary union essentially leading to European political union. When these two contrasting visions were outlined in two very different speeches to two very different audiences in September 1988, they would set in train a chain of developments which would ultimately lead to the second phase of the ideological evolution of the political economy of the developmental market, which would culminate in the 23 June 2016 European Union referendum and "Brexit".

\section{September 1988: The Clash of Two Models of Political Economy}

The earlier era of technocratic pragmatism from October 1961, when the United Kingdom had first sought membership of the European Community, and the first phase of the developmental market from May 1979 when Margaret Thatcher had first led her political party to General Election victory, had been shaped by two key characteristics. First, it had been assumed that domestic programmes of industrial modernization could best be accomplished from within the institutional and policy framework of membership of the European Community. Second, the Labour Party had always been by far the more sceptical of the two major British political parties about the benefits of supranational integration. Indeed, in its 1983 General Election manifesto, the Labour Party had pledged to formally withdraw the United Kingdom from the European Community which it claimed "was never designed to suit us, and our experience as a member of it has made it more difficult for us to deal with our 
economic and industrial problems" (Labour Party, 1983). Indeed, "political burdens" had been placed upon Britain which posed a threat to Labour's "radical, socialist plans for reviving the British economy" (Labour Party, 1983). A speech made by Jacques Delors to the Trades Union Congress at Bournemouth on the 8 September 1988, with the title "1992: The Social Dimension", would change the terms of the debate on the British Left about supranational integration (Delors, 1988).

At three consecutive United Kingdom General Elections (May 1979; June 1983; June 1987), the Labour Party had singularly failed to persuade the British electorate that there was any viable political alternative to Thatcher's developmental market model. Now, Delors offered a vision of how cooperation and solidarity could be reconciled with competition and individual initiative at the supranational level, in a manner which would challenge the hegemony of the developmental market. The Single Market would not diminish the level of social protection offered to workers, but instead improve workers' living and working conditions, and provide "better protection for their health and safety at work" (Delors, 1988). The Commission's proposals would include "The establishment of a platform of guaranteed social rights", including the principle that every worker should have extended the right both to be covered by a collective agreement, and have access to life-long education (Delors, 1988).

Less than two weeks later, on the 20 September at the College of Europe in Bruges, Margaret Thatcher delivered the definitive speech in the whole politics of Brexit by outlining her vision of a developmental market future for Europe. She warned her audience, "We have not successfully rolled back the frontiers of the State in Britain only to see them re-imposed at a European level, with a European super-State exercising a new dominance from Brussels" (Thatcher, 1988). Her alternative vision for Europe would be based upon five guiding principles, the first of which was "willing and active co-operation between independent sovereign States is the best way to build a successful European Community" (Thatcher, 1988). Thatcher's third guiding principle was "the need for Community policies which encourage enterprise", because it was the key for Europe to flourish. The Treaty of Rome had provided the foundation of the developmental market as "a Charter for Economic Liberty", while the lesson of the 1970s and 1980s had been that "central planning and detailed control don't work, and that personal endeavour and initiative do; that a State-controlled economy is a recipe for low growth; and that free enterprise within a framework of law brings better results" (Thatcher, 1988). There must be "action to free markets, action to widen choice, action to reduce Government intervention". Furthermore, the aim "should not be more detailed regulation from the centre; it should be to deregulate and to remove the constraints on trade" (Thatcher, 1988). That meant Thatcher's fourth guiding principle was that "Europe should 
not be protectionist", for "our approach to world trade is consistent with the liberalization we preach at home" (Thatcher, 1988).

\section{The Road to Brexit: The Triumph of New Whiggism}

For domestic United Kingdom politics in general, and the politics of the Conservative Party in particular, the three decades since Margaret Thatcher's Bruges Speech have been dominated by the divisions caused by the conflict between her own and technocratic pragmatism's very different constitutions or power maps for the governance of markets. In this particular regard, in the third and final volume of his Law, Legislation and Liberty, in setting out his developmental market-based vision of "The Political Order of A Free People", Hayek had departed from his earlier optimism concerning the political, economic and moral superiority of the spontaneous order of the free market (as the constitution of liberty), and its capacity to surmount the "chief evil" of the social democratic state which was "unlimited government" (Hayek, 1960: 403). Confronted by the stagflation and trades union militancy of the early 1970s, in which free enterprise and personal freedom could no longer be guaranteed by the free constitution of spontaneous market association, Hayek had advocated the use of law and legislation to devise a model constitution to render "all socialist measures for redistribution impossible" and to secure victory in the "last battle against arbitrary power", namely "the fight against socialism and for the abolition of all coercive power" (Hayek, 1979: 150, 152).

Jacques Delors' September 1988 speech to the Trades Union Congress, and the trajectory of supranational integration under his presidency of the European Commission, threatened to undermine the rolling forward of the frontiers of the developmental market in the United Kingdom. This threat was particularly evident following the December 1991 Maastricht Treaty on European Union which facilitated both an ever-closer political union, with the establishment of the European Union from the 1 November 1993, and deeper economic and monetary union, with the launch of the euro and euro currency area. Margaret Thatcher resigned in November 1990, having failed by a total of four MPs' votes to secure the 15 per cent winning margin necessary to defeat her challenger for the leadership of the Conservative Party, the arch technocratic pragmatist Michael Heseltine. Thereafter, the politics of the United Kingdom's relationship with the European Union have been characterised by one essential continuity and discontinuity with Thatcher's developmental market vision.

The discontinuity has surrounded whether or not Thatcher's vision could be achieved from within the confines of supranational integration, and specifically the Customs Union and Single Market, with its commitment to freedom of movement of goods, services, capital, and people. Throughout her tenure as Prime Minister, and not least in her Bruges speech, Thatcher had been adamant 
that her developmental market objective would be pursued within the parameters of membership of the European Community/Union. Indeed, at Bruges she could not have been more unequivocal in this conviction: "And let me be quite clear. Britain does not dream of some cosy, isolated existence on the fringes of the European Community. Our destiny is in Europe, as part of the Community" (Thatcher, 1988). However, following her resignation as Prime Minister, for an increasing percentage of Conservative Party members, member of parliament, and the wider electorate, the notion that United Kingdom participation in further supranational integration would create an insurmountable obstacle to British sovereignty has led to the demands for the United Kingdom's withdrawal from the European Union. The highwater marks for such sentiments were the 2015 General Election, when a majority of the electorate voted for political parties which advocated an In/Out referendum on United Kingdom membership of the European Union, and the 23 June 2016 referendum itself when 17.4 million or 51.9 per cent of the electorate voted for 'Brexit'.

The essential continuity between Thatcher's Bruges Speech and the Eurosceptic vision articulated by the subsequent generation of developmental marketeers has been in how their model of political economy and prescriptions for the constitution of the market, just like that of technocratic pragmatism, has been founded upon a particular interpretation and understanding of the history of England. Where technocratic pragmatists have based their quest for national modernization via the means of supranational integration on an interpretation of England's (and latterly the United Kingdom's) history which has seen the absence of a developmental state as its definitive feature, the developmental marketeers have advanced a Whig interpretation (Butterfield, 1965) of England's political history which has championed the exceptionalism and superiority of the English constitution, limited government and common law from the signing of Magna Carta in 1215. Latterly, the superiority of the "Anglosphere" (Bennett, 2004), has been held up as a superior alternative political economy to that afforded by the burgeoning "super-state" constituted by the European Union (Hannan, 2012; 2013).

Led by prominent developmental marketeers such as Daniel Hannan, the Conservative Member of the European Parliament for South East England, and former Conservative MP Douglas Carswell, who defected to the United Kingdom Independence Party in August 2014, and kindred spirits within the Conservative Party (Kwarteng et al, 2012) and its allied think-tanks, a political narrative has been articulated in terms of personal liberty, representative government, its uncodified (in a single document) constitution, while the English-speaking peoples of the "Anglosphere" have been presented as the inventors of freedom and the prime movers of "a common Western 
civilization". At the heart of this narrative is "a continuous 'Anglo-Saxon' civilization, whose chief characteristic is a commitment to free markets" (Hannan, 2013: 6). The great threat to this civilization has been held to be posed by the European Union and its alleged ambitions for a European "super-state", or what Hannan has termed "Continentalization" (Hannan, 2013: 371).

Hannan and Carswell have taken their inspiration from "Runnymede", the postscript to Margaret Thatcher's final book, Statecraft. In it, Thatcher had presented Magna Carta as "the supreme and timeless symbol of the liberties of England". It was the political and constitutional bedrock of the rugged individualism which had given "the English, then the British, then the American colonists, and then the wider English-speaking world, characters so irritatingly bent on liberty, so obstinate to right wrongs, so pig-headed in demanding justice" (Thatcher, 2003: 470). Furthermore, Thatcher had concluded: "The demand that power be limited and accountable, the determination that force shall not override justice, the conviction that individual human beings have an absolute moral worth which government must respect such things are uniquely embedded in the political culture of the Englishspeaking peoples. They are the bedrock of civilised statecraft. They are our enduring legacy to the world" (Thatcher, 2003: 471).

This interpretation of England's history has underpinned Hannan and Carswell's campaign to see the United Kingdom exit the European Union. As early as 2005, Hannan and Carswell were among 23 prominent Conservatives who authored Direct Democracy: An Agenda for a New Model Party, in which they advocated the repatriation of powers from Brussels as "a means to an endthe end being a freer and more accountable Britain" (Carswell, Hunt et al, 2005: 95). Moreover, fully eight years before the historic 23 June 2016 referendum vote for "Brexit", Hannan and Carswell had published The Plan, a twelve month agenda for the renewal of Britain which would include "The Great Repeal Bill" to roll back the frontiers of both national and supranational European Union regulation, including "Statutory instruments and regulations enacted under European Works Council Directive rules and European Social Chapter enactments" (Carswell and Hannan, 2008: 186). It cannot have been coincidental that the May Government itself has decided to refer to its legislation to convert the "acquis", the body of European legislation, into United Kingdom law at the point as "The Great Repeal Bill" (May, 2017). More recently, Hannan has depicted a vote for Brexit as an act of liberation from A Doomed Marriage: Britain and Europe (2012; 2016a), and an opportunity for Britain "to define a global vocation again: as a champion of the Commonwealth and Anglosphere, and as the leading global champion of free trade" (Hannan, 2016b: 273). In this regard, Theresa May has defined her postBrexit vision in terms of "Global Britain", with the United Kingdom being the 
global champion of a developmental market agenda of free trade and free markets (May, 2016).

In the aftermath of the 23 June 2016 referendum vote for Brexit, Carswell has claimed "we need a revolution", on a par with England's "Glorious Revolution" of 1688 which installed "England's new Whig elite" and led in turn to the Industrial Revolution (Carswell, 2017: xiii; 203). In a quintessentially Hayekian analysis, Carswell has contended that the restoration of a liberal market order, and escape from the corruption of capitalism by parasitical and sclerotic unelected corporate, bureaucratic, financial and technocratic elites, not least those located in Brussels, will only be possible by reviving a liberal political economy based upon the three principles of independence from foreign rule, dispersal of power among free, internal markets, and interdependence via international trade (Carswell, 2017: 199). Furthermore, Carswell has confessed "it was easy to leave the Conservative Party once I realized I was not a conservative" (Carswell, 2017: 37). In so stating, Carswell was acknowledging that he had undertaken the very same political and ideological journey from conservatism to the economic liberalism of the developmental market which Sir Keith Joseph had admitted to undertaking in April 1974. With Hannan also having launched a new think tank, the Institute for Free Trade (IFT), based at the very Westminster address shared with the Centre for Policy Studies, the think tank originally established by Sir Keith Joseph and Margaret Thatcher, in their actions and thinking two of the most prominent Brexiteers and contemporary prime movers of the political economy of the developmental market have symbolically reconnected with the very ideas and institution which forty-two years earlier had made possible their triumph over technocratic pragmatism in the politics of Brexit at the 23 June 2016 referendum.

\section{Conclusion}

The politics of Brexit, and the United Kingdom's relationship with the process of supranational integration, can therefore be understood in terms of two alternative models of political economy-technocratic pragmatism and the developmental market-which have been advanced as remedies for the United Kingdom's relative decline. Both have viewed the United Kingdom's membership of the European Community and European Union in instrumental terms, as a means to reverse British decline. Technocratic pragmatism has viewed supranational integration as a vehicle for a developmental state-led programme of industrial modernization. At least until November 1990 and the resignation of Margaret Thatcher as Prime Minister, proponents of the developmental market (including Thatcher herself) viewed the Single Market as a means of unleashing a market-led programme of liberalization and deregulation in the spirit of the Treaty of Rome as "a Charter of Economic 
Liberty" for cooperation among independent sovereign states, rather than the basis for an ever-closer political union of the peoples of Europe. Since November 1990, proponents of the developmental market have increasingly identified an ever-closer union of the peoples of Europe as an impediment to their ambition to restore a liberal political economy. They have therefore agitated and campaigned for Brexit.

Each of these models of political economy has been based upon a particular interpretation of England's history. Technocratic pragmatism has viewed the definitive feature of that history as the absence of a modernizing developmental state. The developmental market has viewed England's history from the 1215 Magna Carta to the present day as a continuous Anglo-Saxon civilization, shared among the English-speaking peoples of the Anglosphere, and based upon the English traditions of the rule of the common law, personal liberty, free markets, and limited but representative government.

One of the greatest ironies of the politics of Brexit is that both these interpretations of England's history and political economy have been called into question by recent research and scholarship. The thesis of the absence of a developmental state from England, on account of its having been the first industrial nation and therefore an early rather than late industrializer, has been challenged by the work of historians of England's political economy. David Edgerton, for example, has challenged the widespread impression that England has never possessed "a 'developmental state' devoted to industrial modernization" by detailing how the "liberal militarism" and the technocratic departments of the warfare state in England rendered the role of the English state truly developmental. Indeed, not only has the English state been "the largest 'warfare state' in western Europe" but also the supporter of "civil technological development on a scale more lavish than any other European nation" (Edgerton, 1991: 83).

Sophus Reinert has shown how during the seventeenth century England provided the blueprint for emulation by rival national economies, not on account of the developmental market qualities of free trade, entrepreneurship and limited government, but because "England was among the most interventionist states of its age, and the harrowing success of these policies made England's economy and the ideas on which it was based worthy of guarded emulation" (Reinert, 2011: 6). Thus, John Cary's 1695 Essay on The State of England provided an early blueprint for state-led industrial modernization, incorporating a fourteen-point agenda of administrative guidance for nurturing manufacturing industry almost a century prior to Alexander Hamilton's reports on the state of manufactures in the United States, and more than one hundred and forty years before Friedrich List's Natural 
System of Political Economy (1837) and National System of Political Economy (1841).

Both Hamilton and List's works identified the political economy of England as the role model for national development, but it was England's status as the world's first national developmental state, rather than the limited government of the Whig, neo-liberal, developmental market interpretation of English history, which attracted emulation by rival economies. Indeed, Steve Pincus' research on the "Glorious Revolution" of 1688-9 has shown how the liberalism of that juncture was "not antagonistic to the state" but "revolutionary and interventionist rather than moderate and antistatist" (Pincus, 2009: 8). Moreover, William Ashworth's study of the Industrial Revolution has shown how from 1642 until the early nineteenth century, the role of "a strong dynamic state", "distinctive regulatory institutions" in the shape of the Treasury and the Excise, and "strong state intervention at both the actual site of production, and via the legislative introduction of protective custom tariffs and export bounties" (Ashworth, 2017: 6) was the key to rapid industrialization in England, rather than any developmental market tradition of free trade and free markets.

Since at least the early seventeenth century, England has possessed a developmental state. Technocratic pragmatists have been mistaken in lamenting its absence, and using this as a rationale for membership of the European Community and engagement with the Single Market. Developmental marketeers have been equally mistaken in justifying Brexit in terms of the threat posed by supranational integration towards political union to an eight hundred year-old English liberal political economy of free trade, free markets and limited government. This points to the conclusion that, while the politics of Brexit may have been shaped by important political narratives, both in favour and against British engagement with European supranational integration, some of the underlying conceptions of the history of England, upon which their very different models of political economy have been based, remain highly questionable. 


\section{References:}

Ashworth, J. (2017) The Industrial Revolution: The State, Knowledge and Global Trade, (London: Bloomsbury Academic).

Bennett, J. (2004) The Anglosphere Challenge: Why The English-Speaking Nations Will Lead the Way in the Twenty-First Century, (Oxford: Rowman \& Littlefield).

Bosanquet, N. (1981) "Sir Keith's Reading List”, Political Quarterly, 52 (3): 324-41.

Brack, D. (1989) The Myth of The Social Market: A Critique of Owenite Economics, (London: Link Publications).

Butler, R. (1971) The Art of The Possible: The Memoirs of Lord Butler, (London: Hamilton).

Butterfield, H. (1965) The Whig Interpretation of History, (New York: W.W. Norton).

Campbell, J. (1993) Edward Heath: A Biography, (London: Jonathan Cape).

Carswell, D., Hannan, D. et.al (2005) Direct Democracy: An Agenda for a New Model Party, (London: direct-democracy.co.uk), $<$ https://what wouldvirchowdo.files.wordpress.com/2015/09/direct_democracy_an_age nda_for_a_new_model_party.pdf $>$, (23 May 2018).

Carswell, D. (2017) Rebel: How to overthrow the emerging oligarchy, (London: Head of Zeyus).

Carswell, D. and Hannan, D. (2008) The Plan: Twelve Months to Renew Britain (London: www.lulu.com).

Conservative Party (1947) The Industrial Charter: a statement of Conservative industrial policy, (London: The Conservative Party).

Delors, J. (1988) "1992: The Social Dimension", Speech to the Trades Union Congress, Bournemouth, 8 September.

Edgerton, D. (1991) England And The Aeroplane: An Enemy on a Militant and Technological Nation, (London: Macmillan).

European Commission (1985) Completing The Internal Market, COM (85) 310 final, 14 June (Brussels: Commission of the European Communities).

European Community (1957) Treaty of Rome (Brussels: Commission of the European Community). 
European Community (1984) European Council Meeting at Fontainebleau: Conclusions of the Presidency, 25-26 June (Brussels: European Commission).

Fischer, F. (1990) Technocracy and the Politics of Expertise (London: Sage).

Hannan, D. (2012) A Doomed Marriage: Britain and Europe, (London: Notting Hill Editions).

Hannan, D. (2013) How We Invented Freedom \& Why It Matters, (London: Head of Zeus).

Hannan, D. (2016a) Why Vote Leave, (London: Head of Zeus).

Hannan, D. (2016b) What Next, (London: Head of Zeus).

Hayek, F. (1944) The Road To Serfdom, (London: Ark Paperbacks, 1986 edition).

Hayek, F. (1967) Studies in Politics, Philosophy and Economics, (Chicago: Chicago University Press).

Hayek, F. (1960) The Constitution of Liberty, (London: Routledge).

Hayek, F. (1979) Law, Legislation and Liberty: A new statement of the liberal principles of justice and political economy. Volume 3 The Political Order of a Free People, (London: Routledge and Kegan Paul, 1982 edition).

Heseltine, M. (1987) Where There's A Will, (London: Hutchinson).

Heseltine, M. (1989) The Challenge of Europe: Can Britain Win?, (London: Weidenfeld and Nicolson).

Heseltine, M. (2000) Life in the Jungle: My Autobiography, (London: Hodder and Stoughton).

Heseltine, M. (2017) Industrial Strategy: A Response to The Government's Green Paper, (London: The Rt. Hon. the Lord Heseltine of Thenford CH).

Holmes, M. (1982) Political Pressure and Economic Policy: British Government 1970-1974, (London: Butterworth Scientific).

Hoskyns, Sir J. and Strauss, N. (1977) Stepping Stones, (London: Centre for Policy Studies).

Johnson, C. (1982) MITI and the Japanese Miracle: The Growth of Industrial Policy, 1925-1975, (Stanford: Stanford University Press).

Joseph, Sir K. (1975) Reversing the Trend: A Critical Re-appraisal of Conservative Economic and Social Policies, (London: Barry Rose). 
Joseph, Sir K. (1976a) Monetarism is not Enough, (London and Chichester: Barry Rose Ltd for the Centre for Policy Studies).

Joseph, Sir K. (1976b) "The Job-Creators: The Missing Dimension in our Economic Thinking", Speech given to the Free Enterprise Conference, Collegiate Theatre, London, 30 October.

Joseph, Sir K. (1979) "Industrial Policy and Employment”, House of Commons Debate, Hansard, Volume 967, 21 May, c.707.

Kwarteng, K, Patel, P, Raab, D, Skidmore, C. and Truss, E. (2012) Britannia Unchained: Global Lessons for Growth and Prosperity (London: Palgrave Macmillan).

Labour Party (1983) The New Hope for Britain: Labour's Manifesto 1983 (London: The Labour Party).

Lee, S. (1996) "Manufacturing" in Coates, D. (ed.) Industrial Policy in Britain (London: Macmillan Press).

Lee, S. (1997) "Industrial Policy and British Decline" in Cox, A, Lee, S. and Sanderson, J. The Political Economy of Modern Britain (Cheltenham: Edward Elgar).

Lee, S. (2019) The State of England: The Nation We're In, (London: Palgrave Macmillan).

Macmillan, H. (1934) Reconstruction: A Plea for National Policy (London: Macmillan).

Macmillan, H. (1938) The Middle Way: A Study of The Problem of Economic and Social Progress in A Free and Democratic Society (London: Macmillan).

May, T (2016) Speech to the Lord Mayor's Banquet, Guildhall, City of London, 14 November.

May, T. (2017) "Foreword from the Prime Minister" to Department for Exiting The European Union, Legislating for The United Kingdom's Withdrawal from The European Union, Cm.9446 (London: Her Majesty's Stationery Office).

Pincus, S. (2009) 1688 The First Modern Revolution, (New Haven: Yale University Press).

Reinert, S. (2011) Translating Empire: Emulation and the Origins of Political Economy, (Cambridge Massachusetts: Harvard University Press).

Shand, A. (1984) The Capitalist Alternative: An Introduction to Neo-Austrian Economics, (Brighton: Wheatsheaf). 
Thatcher, M. (1975) The Walter Heller International Finance Lecture, speech at Roosevelt University, 22 September. <https://www.margaretthatcher.org/ document/102465>, (23 May 2018).

Thatcher, M. (1977) Speech presenting The Guardian's Young Businessman of The Year Award, The Mansion House, The City of London, 9 March. $<$ https://www.margaretthatcher.org/document/103334>, (23 May 2018).

Thatcher, M. (1988) Speech to The College of Europe, Bruges, 20 September. $<$ https://www.margaretthatcher.org/document/107332>, (23 May 2018).

Thatcher, M. (1993) Margaret Thatcher: The Downing Street Years, (London: Harper Collins).

Thatcher, M. (1996) Liberty and Limited Government: The Keith Joseph Memorial Lecture, (London: Centre for Policy Studies).

Thatcher, M. (2003) Statecraft: Strategies for A Changing World, (London: Harper Collins).

Ziegler, P. (2010) Edward Heath: The Authorised Bibliography, (London: Harper Press). 